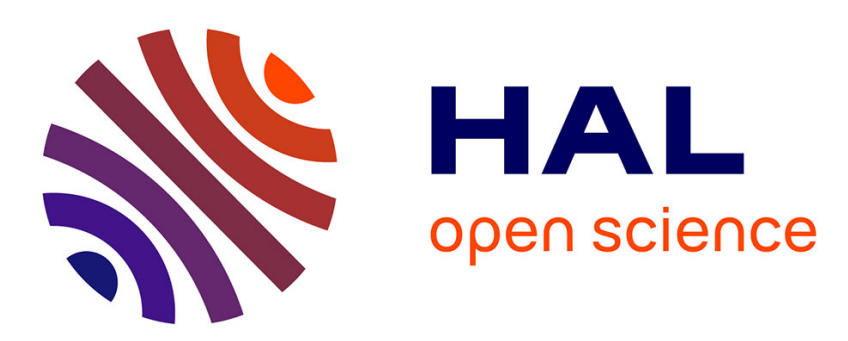

\title{
Rational Herding toward the Poor: Evidence from Location Decisions of Microfinance Institutions within Pakistan
}

Jérôme Monne, Céline Louche, Christophe Villa

\section{- To cite this version:}

Jérôme Monne, Céline Louche, Christophe Villa. Rational Herding toward the Poor: Evidence from Location Decisions of Microfinance Institutions within Pakistan. World Development, 2016, 84, pp.266-281. 10.1016/j.worlddev.2016.02.004 . hal-01362202

\section{HAL Id: hal-01362202 \\ https://hal.science/hal-01362202}

Submitted on 9 Sep 2016

HAL is a multi-disciplinary open access archive for the deposit and dissemination of scientific research documents, whether they are published or not. The documents may come from teaching and research institutions in France or abroad, or from public or private research centers.
L'archive ouverte pluridisciplinaire HAL, est destinée au dépôt et à la diffusion de documents scientifiques de niveau recherche, publiés ou non, émanant des établissements d'enseignement et de recherche français ou étrangers, des laboratoires publics ou privés. 


\title{
Rational Herding toward the Poor: Evidence from Location Decisions of Microfinance Institutions within Pakistan
}

\author{
Jérôme Monne*, Céline Louche*, Christophe Villa
}

*Audencia Business School

\begin{abstract}
Analyzing the geographical location of almost all the microfinance institutions (MFIs) within Pakistan, this paper gives further evidence that microfinance activities do not reach the poorest rural areas. Especially, we explore how this result is driven by the uncertainty faced by MFIs in their location decision i.e. they can hardly predict accurately whether or not they will perform financially. Furthermore, we find that MFIs are spatially clustered and identify three main reasons for this: common attraction factors i.e. the characteristics of one area place fits to the preferences of all MFIs so that they are all located in the same areas; payoff externalities to be collocated; and herd behaviour, i.e. MFIs follows one another. Most importantly, we find that a significant part of this herding process is rational, i.e. early locations of MFIs convey information used by later ones such that it reverses or neutralizes the negative impact of uncertainty resulting then in more locations in needier areas. Since it allows them to be located in poorer areas, MFIs improve the achievement of their social goal. This latter result is rather good news for those who reckon that a better access to financial services enhances economic growth and fosters poverty alleviation. Indeed, rational herding constitutes an endogenous moderator effect to the big issue that financial services penetration is too weak in the poorest rural areas.
\end{abstract}

Keywords: microfinance institutions, location decisions, uncertainty, rational

herding, panel Poisson regression 


\section{Introduction}

In the world's poorest countries, a recurrent point of concern in the field of development is the low penetration of financial services in rural areas, most particularly in the poorest ones. Improving access to financial services is crucial because of the great impact it can have on poverty alleviation and on economic development within these localities. Indeed lack of access to financial services is a leading cause of low development and persisting poverty since it prevents people from seizing investment opportunities and removing tight financial constraints (Banerjee \& Duflo, 2005;

Claessens \& Perotti, 2007). At a macroeconomic level skewed access in favour of relatively well-developed areas is likely to maintain economic inequalities, which are considered to produce lower economic growth (Aghion, Caroli, \& Garcia-Penalosa 1999; Banerjee \& Duflo 2003; World Bank, 2005a). Conversely, financial deepening would yield increasing returns to scale benefiting the whole economy within such regions (Greenwood \& Jovanovic, 1989; King \& Levine, 1993; Pagano, 1993).

An uneven spatial distribution of financial services raises the question of the location decisions of financial institutions, more especially those of microfinance institutions (MFIs thereafter), which are perceived as, and expected to be, the best equipped to reach the poor in the most remote areas.

However, MFIs' decisions are shaped by strong financial constraints, i.e. they have to streamline costs and are required to get a high repayment rate from their customers. Indeed, donors' subsidies depend widely on a good repayment performance; more directly, displaying low default rates is a mandatory condition to achieve the selfsustainability aimed for by MFIs. In addition, MFIs' self-sustainability depends on their ability to control costs. Such financial efficiency stands in contradiction with the low 
creditworthiness of borrowers and the higher transaction costs generally associated with the provision of financial services to the rural poor. Consequently, although they do have a social commitment, MFIs might not primarily choose to be active in the poorest, most remote rural areas (Sharma \& Zeller, 1999).

Moreover, since it is made prior to establishment, any location decision is inherently uncertain. This may further accentuate the MFIs' move away from poorest areas. As the levels of poverty and remoteness increase, the probability of a successful establishment in terms of financial performance tapers increasingly. The existence of some highperforming MFI branches in adverse areas has been well described in the literature; but no systemic rule can be drawn from this that would describe the environmental features of a region required to ensure the successful establishment of a branch. From one place to another, it is complicated to distinguish among several types of poverty, some of which are easier to deal with than others. Moreover, it can be hard for an MFI to know exactly which level of poverty it will be able to handle. Traditional prospecting tools such as statistics on poverty appear to have little relevance, which implies looking for more idiosyncratic information that is also less available and less easy to interpret. Therefore, though MFIs may know it is possible and socially desirable to reach out to poorer regions, the uncertainty, i.e. the risk of a wrong decision, is so high that they may be reluctant to enter these types of areas - at the expense of people living there.

In this paper we flag an important issue, namely that in this context of uncertainty MFIs may rely upon a very valuable source of information: past location decisions made by other MFIs. Proceeding to observational learning (Banerjee 1992; Bikhchandani, Hirshleifer, \& Welch 1992; Welch 1992) from earlier institutions' location decisions, MFIs can make a rational Bayesian inference of regions where it must be possible to run 
sustainable microfinance operations. As a consequence, regions that have already attracted some MFIs may be more likely to attract more MFIs' subsequently: this is called rational herding (Zhang \& Liu 2012).

Rational herding of MFIs would be rather good news for those who believe that access to financial services has a positive impact on poverty alleviation and economic development. It would allow MFIs to reach poorer, more remote locations. As those areas mean a lot of uncertainty for MFIs (especially in terms of financial performance) information they can infer from the presence of other MFIs (i.e. through observational learning) in one of these areas may have much influence on their decision to finally settle there. Conversely, such influence is likely to be lower in wealthier regions, where MFIs are faced with lower uncertainty about the financial performance of their branches.

Observational learning allows MFIs to make more social location decisions with a greater guarantee to achieve a good financial performance. They should therefore seize this opportunity, primarily because reaching out to the poorest is an argument to maximize in their utility function.

Herding has been widely studied in finance, economics, management science, and many other research fields in which location or allocation decisions have to be made under uncertainty ${ }^{1}$. In particular, empirical research projects analysing herd or imitation behaviour in location decisions have been booming. At an international level, much attention has been paid to this behaviour in the foreign establishment of multinational firms (Belderbos, Olffen, \& Zou 2011; Hahn, Doh, \& Bunyaratavej 2009; Gimeno et al. 2005; Head, Mayer, \& Ries 2002; Henisz \& Delios 2001). At a city level (Chang, Chaudhuri, \& Jayaratne, 1997) analysed rational herding in the establishment of bank

\footnotetext{
${ }^{1}$ See Hirshleifer and Teoh (2003); Bikhshandani and Sharma (2000); Devenow and Welch (1996) for literature reviews of herding in the financial sector.
} 
branches in areas of New York. More theoretically, Suire \& Vicente (2009) analysed the role of mimetic behaviour in firm clusters formation.

In order to verify the likelihood of herd behaviour, we analysed 588 location decisions taken by 26 MFIs within Pakistan over a period stretching from 1994 to 2011 . In the same way as the literature analysing location decisions, our empirical test of herding relies on non-linear panel models in order to capture the likelihood that an MFI will open a new branch in a region if it knows that MFIs have already been set up there. It is based upon the counting of MFI branches at Tehsil ${ }^{2}$ level and the year of their establishment.

Those variables have been extracted from a brand new database that we generated from a map released very recently on the websites of the Pakistan Microfinance Network's (PMN) and the Pakistan Poverty Alleviation Fund's (PPAF) ${ }^{3}$. We also used Pakistan census data, from which we extracted (at a Tehsil level) a certain number of crossregional features likely to reflect variation in the level of poverty and remoteness from one place to another. We used Tehsil-level fixed effects in our panel Poisson regressions to disentangle herd behaviour from mere sequentially correlated entry decisions within a Tehsil. More precisely, the methodology we applied to identify rational herding, i.e. how herding intensity is likely to vary depending on the level of poverty of a place, was inspired by Zhang \& Liu (2012). This consists in testing the influence of interaction variables between the lagged presence of MFIs and the poverty characteristics of a place.

Our main results find evidence of 1) an overall low presence of microfinance in Tehsils that are both remote and poor; 2) herd behaviour, such that after having controlled for the heterogeneity of places, the lagged presence of MFIs positively increases the likelihood

\footnotetext{
${ }^{2}$ A Tehsil is the third administration level within Pakistan. A Tehsil is an administrative division of India, Pakistan and some historical states of South Asia - an area of land with a city or town that serves as its administrative centre, with possible additional towns and a number of villages).

${ }^{3}$ Available under the following URLs: http://www.microfinanceconnect.info/ or http://www.ppaf.org.pk/
} 
of a subsequent entry; 3 ) rational herding towards the relatively weakly developed Tehsils, i.e. the likelihood of herding increases with the degree of poverty of a Tehsil.

To the best of our knowledge, our study is the first to investigate the herd behaviour of MFIs - the most important actors of microfinance in the field.

Thus it contributes to the relatively scarce literature analysing the determinants of location decisions by MFIs (Sharma and Zeller, 1999; McIntosh, de Janvry, \& Sadoulet, 2005; Fruttero \& Gauri, 2005). Our preliminary results are in line with those of previous studies and thus confirm the fact, in Pakistan's case, that microfinance providers tend to be more present in relatively well-developed areas.

However, by identifying a rational herding, we raise the important point that MFIs may have real willingness to solve their informational issue in order to reach out to poorer areas. Also, to the extent that our model could be generalised, it has a predictive power regarding the future geographical pattern of microfinance establishment, i.e. the positive influence of pioneering MFIs grows with the level of poverty they are prepared to take on.

In terms of methodology, we contribute to the literature by applying the recent work of Zhang \& Liu (2012) to location decisions; this captured the rational herding of micro lenders on an online peer-to-peer crowd funding website. The main interest of this approach is to bring out whether herding occurs as a mean to struggle against the uncertainty that might have prevented MFIs from reaching out to a poor, remote area. The idea is that herding is rational to the extent that it will eventually allow an MFI to open a branch in a place that it would not have chosen before due to the poverty features that are at the basis of strong uncertainty.

The remainder of the paper is organised as follows. In the next part we will present the theoretical background concerning the determinants of MFIs' location decisions. A third 
part will display our data, the methodology employed to test our hypotheses and the results. Our fourth part will draw some conclusions from the study.

\section{Theoretical Background}

The location decisions of MFIs may be sensitive to the level of poverty in the target area. Overall, for financial and informational reasons, MFIs may not primarily choose regions featuring a high level of poverty and remoteness. However, their uncertainty may be mitigated by their peers' earlier location decisions and herd behaviour may occur.

\subsection{The impact of risks and uncertainty on location decisions}

On the basis of a survey of MFIs in Asia, Africa and Latin America conducted in 1999 by the International Food Policy Research Institute (IFPRI) team on microfinance, Lapenu \& Zeller (2001) noted that there were "Only 19.5 percent of MFIs specialized in rural areas where the majority of the poor in the developing world live". This statement provides a good introduction to the problem faced by microfinance in reaching the poorest people in rural areas and a fortiori those in poorer, remoter ones. Whether designed to diminish dependency on donors or to make a profit, all MFIs are in search of good financial performance (Godquin, 2004). Consequently, expectations concerning borrowers' creditworthiness and costs; and the accuracy of these expectations are very likely to play an important role in the highly strategic decision of where to be located.

\subsubsection{Low creditworthiness}

The greatest part of the problem comes from the fact that people whose profile combine poverty with living in a rural area are routinely assessed, even by microfinance practitioners, as less creditworthy. Low creditworthiness raises the perceived risk (for 
MFIs) of lower repayment performance (Sharma \& Zeller, 1999; see also the survey of Johnston \& Morduch, 2008 for Indonesia). Borrowers’ low entrepreneurship opportunities, yielding weak and vulnerable returns in rural poor areas, may make MFIs less inclined to be located in this type of area, considering their financial constraints (Shaw, 2004; Sharma \& Zeller, 1999). Population in the poorer regions is also more likely to be 'vulnerable' rather than merely 'poor'. Vulnerability refers to people whose well-being is likely to decline after the occurrence of a shock and who are unable to insure against idiosyncratic risks (World Bank, 2001; Amin, Rai, \& Topa, 2003). According to Amin, Rai, \& Topa (2003), vulnerable borrowers represent greater risks to microfinance providers.

Moreover, in areas characterised by an homogeneous level of poverty, a trade-off strategy (Copestake, 2007), i.e. the possibility to up-scale the supply of credit to wealthier and less risky customers in order to improve overall repayment performance, is naturally less feasible.

From an empirical point of view, Khandker, Khalily \& Khan (1995) have pointed out the negative link between the geographical features of rural poverty and repayment performance. They found that the leading, experienced Grameen banks in Bangladesh had known a significantly lower repayment rate in rural areas featuring an overall environment of poverty (e.g., no rural electrification, poor quality of roads, poor basic educational infrastructure and low presence of commercial banks). Moreover, other studies examining the financial efficiency of rural microfinance programmes reveal mixed results in the repayment performance from one institution to another but also within institutions themselves (Desai \& Mellor, 1993; Sharma \& Zeller, 1997). The creditworthiness issue may well lead MFIs to promote relatively well-developed areas at the expense of the neediest, most remote regions. 


\subsubsection{The costs issue}

The cost issue arises from the typically small amounts demanded by the very poor; this raises the loans' unit costs in terms of screening, monitoring and administration (Hermes, Lensink, \& Meesters, 2011). More particularly in rural regions, monitoring, screening but also repayment collection are more complicated and costlier since customers tend to be very scattered and distant from the branch (Yaron, 1994; Basu \& Srivastava, 2005). Moreover, in those areas, the presence of a commercial bank is less likely and hence the distance of an MFI's branch from the branch of a commercial bank is likely to be greater. This can be problematic as some MFIs' branches depend on a commercial bank branch for cash operations (withdrawals or deposits), hence the cost of cash transfers in the most remote areas is likely to be higher (Sharma \& Zeller, 1999). The average cost of a loan can be reduced by decreasing the outreach, i.e. serving wealthier borrowers who, typically, ask for larger amounts (Cull, Demirgüc-Kunt \& Morduch, 2009; Hermes, Lensink \& Meesters, 2011). This strategy is obviously harder to implement within the poorest areas where poverty levels are quite homogeneous among the population.

\subsubsection{Uncertainty about financial performance}

The usual approach governing a location decision consists in gathering objective, observable environmental characteristics of alternative areas, in order to eventually select the region that matches the organisation's objectives and constraints best. It is not however simple: for any organisation, a location decision remains basically uncertain since it relies entirely on expectations (i.e. potentially 'noisy') concerning the impact (positive or negative) of these environmental characteristics on the payoff of operations. 
Finally, the weight of uncertainty is more significant if the potential impact of a wrong location decision is high.

For socially-motivated MFIs that both aim to reach the largest poverty level they can take on and maximise their repayment performance (Godquin, 2004), the uncertainty and the weight of uncertainty in their location choice is likely to be all the more oppressive as the level of poverty and remoteness increases among alternative regions to be selected. As a consequence, they represent a strong obstacle to establishment in such poor regions.

\section{Uncertainty}

Uncertainty may be a barrier to targeting the poorest areas because of the difficulty to assess the boundaries up to which poverty does not threaten repayment performance. (Sharma \& Zeller, 1997) stressed that Bangladeshi NGOs using group-based lending had experienced good repayment performance in "relatively remote communities and even in communities that were likely to have higher than average rates of poverty" but these results are outweighed by the study of Khandker, Khalily \& Khan (1995) that found that the Grameen Bank in rural Bangladesh, also using a group-based lending method, exhibited decreasing repayment rates as the level of development indicators decreased from one area to another. Moreover, if in the literature some case studies do describe success stories of MFIs in very isolated areas (Park \& Ren, 2001) suggesting that in theory 'it is possible' to get good financial results (at least in terms of repayment), in practice, however, these cases tend to be exceptions. If we put these studies in perspective, we can see what a hard task it is for MFIs to distinguish beforehand between a 'relatively poor' region where they could financially perform well and a 'relatively poor' one where they could not. The difference is likely to be difficult to detect. Besides, 
it probably rests on idiosyncratic characteristics that are rather hard to identify, and whose impact on the MFIs' activities is difficult to anticipate.

Statistical poverty indicators (e.g., level of income, level of literacy) publicly available from statistical institutes roughly enable us to assess the very nature of poverty. As emphasised in Ravallion (2001), a more accurate assessment 'beyond the average' is necessary if we wish to understand precisely how idiosyncratic features change from one area to another. Indeed, even two regions with an average level of poverty measured in terms of income would not predict the distribution around the average - although this is fundamental. Furthermore, poverty can take very different forms, depending on the area concerned, and therefore influences randomly the performance of an institution. A good illustration is the definition of vulnerability in Amin, Rai, \& Topa (2003): it concerns people who are "unable to smooth consumption in the face of idiosyncratic income fluctuations". As vulnerable people are also likely to be poor, identifying this feature beforehand is quite tricky; it is clear that MFIs are less comfortable with serving this type of customer but could still bring very valuable services to less vulnerable poor people.

The combination of all these elements may make it difficult for an MFI to make a realistic assessment of its ability to succeed. In this context, the probability of a mistake is higher; an MFI would probably decide to reduce its poverty targeting ambitions by choosing to be located in a more developed area even though there is some evidence that a successful location in a poorer region is possible.

\section{Impact of a wrong decision: the weight of uncertainty}

An additional problem associated with uncertainty is the impact of a wrong decision. In the poorest areas, conversely to what may happen in the wealthiest ones, the uncertainty faced by MFIs is not taken into account solely as a higher probability of 'a poor financial 
performance' but also as the anticipation of higher losses associated with this probability. These higher expected losses are firstly linked to the aforementioned trade-off strategy, which is less viable and, secondly, to the reputational concerns of decision-makers, two points that we will now elaborate upon.

Indeed, misguided establishment in a poor area is much more difficult to compensate for, which increases the probability of failure on financial grounds. These would be: a less than expected creditworthiness of the clientele and higher transaction costs. As we already noted previously in this paper, a trade-off strategy - i.e. portfolio diversification involving wealthier customers - is less feasible (Godquin, 2004; Copestake, 2007). Consequently, in this type of poor region, a misguided decision is more likely to lead to a failure of the branch.

Secondly, a misguided decision is bad for the reputation of those who have made it. The governance scheme of an MFI includes very important stakeholders, upon which the activity of the MFI can rely heavily (Hartarska, 2005; Mersland \& Strøm, 2009). Future fund provision by donors, equity investors or creditors will depend on the financial performance that the MFI is able to achieve. Generally less informed than managers inside MFIs, these fund providers may hold the prior belief that it is too risky to venture into an excessively poor or remote region. Though a manager may expect a positive outcome from a region with such characteristics, if (s)he is not $100 \%$ sure of the success potential of the location, (s)he may decide not to open a new branch because a wrong decision might be assessed as a poorly informed or hazardous one that would weaken the MFI's good repute. Conversely, in a wealthier area, bad financial performance of a branch will be attributed to bad luck because everybody thought it was a prudent choice. 


\subsection{Herding}

Herd behaviour is the duplication of past location decisions made by peers. The literature distinguishes between rational and irrational herding. Herding is irrational if it consists in passively mimicking the previous choices of others without any apparent reasons. On the contrary, it is rational when agents respond to additional information that allow them increasing their expected utility in an uncertain framework.

\subsubsection{Irrational herding}

The literature on herding has a dual character: as explained above, herding can either be rational or not. Studies in behavioural finance have emphasised herding motivated either by the irrationality or the bounded rationality of some investors. Referring to the Animal Spirit of J.M. Keynes, behavioural finance authors have put forward the idea that some market phenomena - such as speculative bubbles or excessive volatility - may arise from the psychology and sociology of investors; they cannot be explained solely by utility maximising behaviour (Shefrin, 2000; Shleifer, 2000; Shiller, 2003).

Zhang and Liu (2012), analysing lenders' herding in online peer-to-peer microloan markets, argued that irrational herding may reinforce the momentum towards potential borrowers that primarily exhibit creditworthiness characteristics. Irrational herders do not really infer any additional information from peers but passively mimic others' choice in funding the most salient borrowers.

In the field of MFIs' location decisions, irrational herding would result in reinforcing the presence of MFIs within urban and/or relatively well-developed areas, which are primarily selected for their safer characteristics to pursue sustainable microfinance. Indeed, for pragmatic financial reasons, the momentum of MFIs' location decisions favours those areas so the likelihood of an earlier presence is higher there. Consequently, 
by passively mimicking the behaviour of the herd, MFIs entering the market later would merely amplify this main trend favouring rich areas.

The amplification process through irrational herding is consistent with what we assumed in the previous section about uncertainty. The degree of uncertainty of a location decision is lower for relatively wealthy areas, i.e. the informational issue (concerning the financial performance of the future branch) is less prominent. To the extent that more intense herding would occur towards these wealthy areas, we should not conclude that this is a rational process, since there is less information to infer.

Moreover, we assumed that a rational MFI would seek to maximise its utility function and that this function includes a social reason, i.e. reaching out to poorer areas. If herd behaviour is oriented towards the richest areas, it is obviously in contradiction with this maximisation process. In other words, in this latter case, herding is probably less a solution for solving uncertainty (see next section on rational herding) than a mere conformity effect, most probably responding to the psychology of the decision-maker and/or the sociology of the institutional framework (Schiller, 2003; Zhang and Liu, 2012; Cai, Chen \& Feng, 2009). Therefore, following this rationale, irrational herding can be identified when we witness a significant increase in the likelihood of later MFIs entering areas that exhibit a combination of wealth features and the earlier presence of MFIs.

\subsubsection{Rational herding: solving the problem of uncertainty}

MFIs' utility is an increasing function of their ability to serve the poorer while meeting a good financial performance (Cull, Demirgüç-Kunt \& Morduch, 2009). As mentioned above, MFIs are faced with an informational issue that makes more difficult the achievement of this double bottom line; as they increase the targeting of poorest areas, their financial performance becomes more and more uncertain. One answer to this 
problem lies in observational learning (Banerjee 1992; Bikhchandani, Hirshleifer, \& Welch 1992; Welch 1992), i.e. observing where previous MFIs have been located; this can mitigate the uncertainty faced by MFIs about their financial performance.

Observational learning is therefore a rational way for the MFI to meet both its social commitment (i.e. serve the poor) and its financial obligations (good financial performance).

\section{Mechanisms of rational herding}

The uncertainty faced by MFIs in location decisions raises an informational problem. The fear of taking a misguided decision keeps them away from some areas since they cannot assess accurately enough the environmental determinants of a good/bad financial performance. However, they can gain very valuable additional information by observing the previous location decisions of their peers, thus proceeding to social or observational learning (Banerjee 1992; Bikhchandani, Hirshleifer, \& Welch 1992; Welch 1992).

When they analysed the foreign location decisions of multinational firms, Belderbos, Olffen, \& Zou (2011) explained how observational learning would occur: "If firms cannot perfectly observe and analyze all relevant environmental factors and are uncertain as to the comparative advantages of alternative locations, they may instead derive relevant information from observing prior entry location choices by other firms." Observational learning is a strong driver of herding because the actions of early decisionmakers lead subsequent ones to infer that they had good reasons / reliable information justifying their choices (Zhang \& Liu, 2012).

The underlying mechanism is that all individuals have private information that becomes public once they have made their choice. Later decision-makers also have their own private information but this becomes less relevant once early players have selected their options. Indeed, the observable actions of early decision-makers reveal and convey some 
valuable information, making the prior beliefs of later ones less relevant. Consequently, an MFI's assessment of an area made afterwards, i.e. after having observed others' location decisions, may be different from what they would have concluded beforehand, i.e. without having observed others - and could lead them to a different location choice. An MFI can, for instance, be very uncertain about the financial performance it could achieve in one poor region; conversely it may have few doubts about the prospects for a good performance in a relatively well-developed urban area. If it is first to enter the market (i.e. before all other MFIs), it probably will not take the risk to go to the poor area. If instead it has to decide in second position and if the first MFI has decided to locate in the less developed region, this sends a positive signal that may mitigate the prior uncertainty of the second MFI and may increase the probability of entry in this poor region. Figure 1 represents how rational herding may occur and how it could allow reducing the MFIs' trend to foster location in relatively well developed areas.

\section{Figure 1: rational herding}

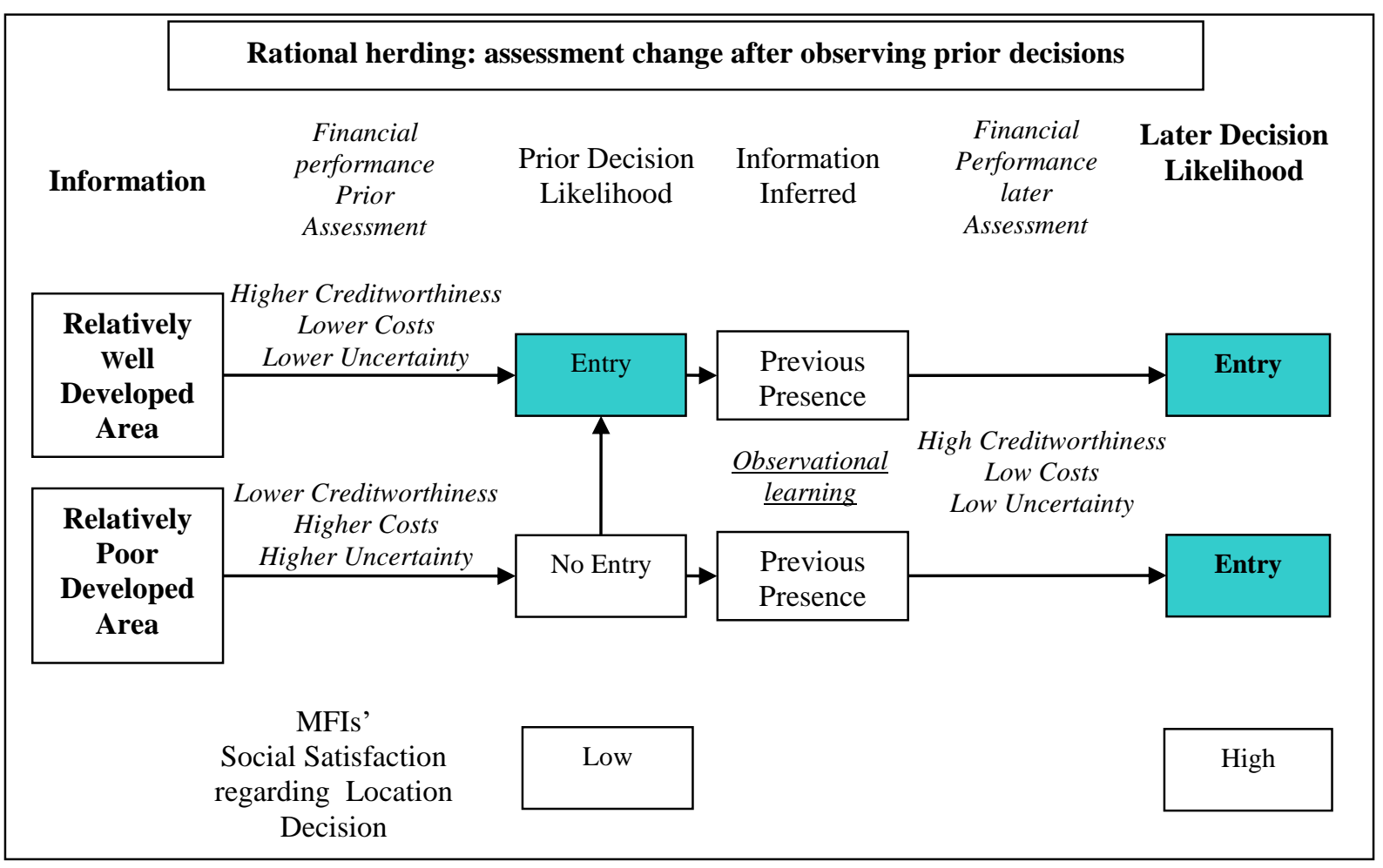




\section{Data, methodology and results}

\subsection{Data}

The first set of data at our disposal comes from the mapping of microfinance activities in Pakistan made available by the Pakistan Microfinance Network (PMN) and the Pakistan Poverty Alleviation Funds (PPAF). The map allows us to track the branch location of 26 microfinance institutions until 2011 (included). These MFIs worked with more than $90 \%$ of the borrowers served by the microfinance industry in Pakistan in $2011 .{ }^{4}$ For each branch of each banking institute, metadata are available and state the year of establishment of the branch. This covers the opening of 949 branches, 588 first entries of an MFI into a Tehsil, and over 397 Tehsils ${ }^{5}$ within Pakistan. Our data set allows a good overview of the growth of the microfinance sector over the period concerned. Table 1 sums up the main statistics at a Year $\times$ Tehsil level. We can note for instance that the average number of MFIs per Tehsil increased from 0.03 in 1993 to 1.47 in 2011.

We also obtained the 1998 census data. For each Tehsil we thus have data on the population, the number of households, the rural/urban proportion of households, the literate population by gender and the type of habitat of the population: this can be either kacha housing (mud houses), pacca housing (brick-and-mortar houses) or an intermediate type called semi-pacca housing. Variables extracted from these sources are

\footnotetext{
${ }^{4}$ Calculation on the basis of information available on the country profile of Pakistan on the MIX Market.

5 This number does not include Jammu and Kashmir, which are the subject of political tension between Pakistan and India. We also withdrew 7 Tehsils for which no data were available in the census and where no microfinance activities had been reported in the mapping (Babuzai, Bahrain, Barikot, Charbagh, Kabal, Kalam, Panjpai).
} 
presented in our summary statistics. We will define these variables in greater detail in the next part (summary statistics are reported in Table 1).

At the institution level, as regards the social inclination of organisations included in our data, it is worth noting that all are stated as microfinance institutions that officially claim that their mission is to serve the poor and to participate in development. This also applies for institutions listed as microfinance bank (i.e. falling under the supervision of the State Bank of Pakistan). We find that a clear social orientation has been reported in their Mix Market profile: a first one talks about reaching the 'disadvantaged population', a second one wishes to 'achieve a prosperous, equitable and poverty free Pakistan', a third one describes its mission as improving 'outreach' and 'accessibility', which 'strengthens [the] economic base'. A fourth microfinance bank talks about 'empowerment at the bottom' and finally the fifth claims that it will 'go where no (commercial) bank has gone before'. These self-reported intentions justify well that even more profit-oriented institutions integrate social preferences in their utility functions.

From a financial point of view, importantly, we note that apart from the five microfinance banks mentioned above, only nine of the 21 remaining MFIs explicitly mentioned financial sustainability or their willingness to be financially sustainable. However, 24 institutions rely, or are seeking to rely, on charged funds (essentially loans or equity) which suggests an obligation (and the willingness) to display safe financial returns. On the other hand some rely on subsidies; we know that these are essentially conditional on financial efficiency.

Both social and financial requirements are stricter for 19 MFIs funded by the Pakistan Poverty Alleviation Fund (PPAF), which states in its eligibility criteria that "The eligible partner organisations are also expected to have demonstrated track record, financial sustainability and participatory development within their functions. The selection of 
partner organisations is an on-going process, whereby new ones are added and others who have not performed may be excluded." (We report in Table A1 of the appendix the summary of the preference characteristics reported by MFIs in their Mix Market profiles.)

\subsection{Methodology}

The methodology we used to identify rational herding is empirical and is inspired by the work of Zhang \& Liu (2012). To identify the existence of herd behaviour we determined whether the number of MFIs already present in a Tehsil had increased the likelihood that a later MFI entrant would open for the first time one (or more) branch(es) in this Tehsil. To do so we ran a panel Poisson regression.

Poisson distribution is especially appropriate to model empirically an endogenous counting variable containing a lot of 0 outcomes, which fits in well with our case since in many Tehsils, over many years, no new branch had been opened (Wooldridge, 1999). The panel structure of our dataset allows us to introduce Tehsil fixed effects to overcome the issue of unobservable heterogeneity from one Tehsil to another. As we have historical data of MFI locations over years and across Tehsils, we could also build variables that allow controlling for payoff externalities. Finally, rational herding is demonstrated by the use of interaction variables that combine our lagged-presence-ofMFIs variable (that we assume increases the entry likelihood under the hypothesis of herding) with each of our uncertainty measures (approximated by Tehsil features of poverty or remoteness) that are assumed will decrease the entry likelihood of an MFI.

We validate the hypothesis of rational herding if interaction variables exhibit a positive impact on the entry likelihood of MFIs within a Tehsil in comparison with the negative impact of uncertainty observed during the previous steps of our analysis. We argue that 
herding is rational if it either reverses, cancels or moderates the main negative impacts of uncertainty on the entry decision.

\subsubsection{Preliminary analysis: sequential correlation}

For each location (e.g., Tehsil) and for each year we are able to identify the number of MFIs present, the number of branches they had and the year they opened.

We denote $y_{i, t}$, where $\mathrm{t}=1994,1995, \ldots, 2011$ our dependent variable representing the location decision of an MFI. This is thus for a Tehsil $\mathrm{i}$ the number of MFIs opening at least one branch for the first time in year $\mathrm{t}$ (MFI 1st entry).

We denote $Y_{i, t-1}$ the presence of at least one MFI that we expect will have influenced the location decisions of subsequent MFIs; it is then a binary variable which takes the value 1 if at least one MFI is already present in a Tehsil $i$ at the end of the previous year (lag presence) or else the value 0 . A naive test of herding consists in looking at the sequential correlation (Zhang and Liu, 2012) of entry decisions in a Tehsil such that $y_{i, t}$ is positively correlated with $Y_{i, t-1}$, the lagged presence of MFIs. This test would be expressed as shown in Equation (1) below, in which the dependent variable is $y_{i, t}$ and the regressor is $Y_{i, t-1}$ :

$$
y_{i, t}=\alpha Y_{i, t-1}+\varepsilon_{i, t}
$$

and where $\varepsilon_{i, t}$ is the term of error, and $\alpha$ is the coefficient to estimate that would reflect the sequential correlation. Sequential correlation is not a proof of any herd behaviour since, as assumed in our theoretical framework, this correlation may come from other causes leading MFIs to be clustered. Those causes that we need to control are detailed in the next section. 


\subsubsection{Herd behaviour: identification issue and control variables}

At first glance, herd behaviour is isomorphic to any type of clustering behaviour that occurs sequentially. In order to emphasise true herd behaviour and especially an information-based one, we need to control for other causes of clustering. We identify three main reasons why we need to introduce control in our statistical approach if we wish to isolate the effects of herding: payoff externalities to be collocated, MFIs-tofollow heterogeneity and Tehsils co-founding factors of entry. We then have

$$
y_{i, t}=\alpha Y_{i, t-1}+\beta_{1} X_{i, t}+\beta_{2} Z_{i}+\beta_{3} Y_{i, j, t-1}+u_{i}+v_{i, t}
$$

where $X_{i, t}$ are the time varying attributes controlling for payoff externalities, $Z_{i}$ represents Tehsil invariants attributes controlling for some heterogeneity; $u_{i}$ the Tehsil fixed effect controlling for unobserved heterogeneity and $Y_{i, j, t-1}$ controlling for MFIs-tofollow specific effects that may control for heterogeneity in the preferences of some (un)followed early MFIs.

Explanations concerning the four attributes: $X_{i, t}, Z_{i}, Y_{i, j, t-1}$ and $u_{i}$ are provided in the paragraphs below.

a) Payoff externality variables: $X_{i, t}$

The time varying Tehsil attributes $X_{i, t}$ are introduced to control the possible presence of payoff externalities (Katz \& Shapiro, 1985; Drehmann, Oechssler \& Roider, 2007). They contains the following two variables: the variable Pioneer_age is the duration in years stretching from the first year an MFI (i.e. pioneer) came into the Tehsil until the year 
$t-1$, it is expressed in years. We expect the Pioneer_age to reflect the maturity of the market place; the variable lag branches density is the number of branches per inhabitants in a Tehsil at the end of the year $t-1$. It is the ratio between the lagged number of branches within a Tehsil and the population of this tehsil. It reflects thus the concentration of a market. The expected effect of these two variables is ambiguous such that they could accelerate or moderate a herding behavior.

From a financial point of view, a mature and concentrated market can, on the one hand, benefits to all market participants through more experienced and sophisticated consumers that are thus less costly to monitor and train; and through higher returns to scale at the macroeconomic regional level (Greenwood and Jovanovich, 1989). On the other hand, it would entail a fierce competition that could be problematic on the repayment performance of customers (McIntosh et al, 2005), and that would require greater financial efficiency (Hermes et al, 2011). From a social point of view, a mature and concentrated market provides less opportunities to have a high marginal impact on poverty. In comparison, it would be socially more valuable to to reach the neediest, excluded ones in places where microfinance is still in its infancy. However, answering the questions of whether payoff externalities would be positively or negatively correlated with the entry likelihood, and what kind of payoff externalities is exactly at stake, is not the point of this study. Their presence in our regressions is important especially since it allows to disentangle two herding causes that could have been confused if we had analysed solely the lagged presence of MFIs. For instance, if there is indeed a higher entry likelihood because of these payoff externalities it is important to control them in the regressions in order to not overestimate the impact of the sole lagged presence which is assumed to reflect herding caused by informational issues (Zhang and Liu, 2012). 


\section{b) MFIs-to-follow heterogeneity: $Y_{i, j, t-1}$}

Literature on herd behaviour caused by informational issues often claims that a reason for herding is that later individuals assume that earlier ones have similar preferences.

Though we emphasised in our data presentation that MFIs do seem to have common preferences (both reaching out to the poor and achieving at least some degree of financial sustainability), MFIs may have some very specific characteristics that will influence their later-entrant peers to a greater or lesser extent. For instance, one specific incumbent MFI can be known for its geographical anchoring such that the information inferred from its location signals more strongly and more accurately the "quality" of the place. Another instance is that some incumbent MFIs can display differences, in the type of loan they provide (e.g. technology used, size of the loans...), or in the performance they obtain (e.g. repayment rate) and, for later MFI, depending on this, this could make colocation more or less attractive. Statistically, we would be misled concluding to a herding behavior while in reality, MFIs all follows one specific leading MFI. Moreover, in this paper we want to make clear that a herding behavior is strongly likely because it relies on the information conveyed by the previous location decisions per se, regardless of the identity/technology/performance of those who made them.

We consider problematic if such a MFIs to follow effect occurs since it would lower the credibility to find out similar evidence of herding in other countries or other framework. Indeed if in reality our result on herding hold only on the very specific influence of one or two institutions with very particular characteristics, our conclusion would lose in transferability and the external validity of our theoretical framework would be weaken. 
To ensure that the herding that we assume to find is blind of the specific identity of the MFIs previously present, we include the vector of variables $Y_{i, j, t-1}$ which contains a dummy variable for each of the 26 MFIs lagged presence. For each MFI, $Y_{i, j, t-1}$ takes the value 1 if the MFI $\mathrm{j}$ were present in the Tehsil $i$ at the year $t-1,0$ elsewhere. After we control the heterogeneity of the MFIs-to-follow, we expect we will be able still to conclude that there is a herding behavior of MFIs that rely on observing microfinance institutions in general and not specifically some of them.

To verify this empirically, $\alpha$ should remain positive and significant while MFIs-tofollow dummy variables are included.

Table 1: summary statistics

\begin{tabular}{|c|c|c|c|c|c|c|c|c|}
\hline $\begin{array}{l}\text { VARIABLE } \\
\text { TYPES }\end{array}$ & VARIABLES & VARIABLECONCEPTS & VARIABLE LABELS & obs & mean & std dev & $\min$ & $\max$ \\
\hline \multirow{2}{*}{$\begin{array}{l}\text { dependent } \\
\text { variables }\end{array}$} & \multirow{2}{*}{$\boldsymbol{y}_{i, t}$} & \multirow{2}{*}{$\begin{array}{c}\text { entry } \\
\text { variables }\end{array}$} & MFI 1st entry & 7543 & 0.08 & 0.30 & 0 & 3 \\
\hline & & & pioneer & 7543 & 0.03 & 0.18 & 0 & 3 \\
\hline \multirow{3}{*}{$\begin{array}{l}\text { time-varying } \\
\text { predictors }\end{array}$} & $Y_{i, t-1}$ & herding variable & lag presence & 7146 & 0.28 & 0.45 & 0 & 1 \\
\hline & \multirow{2}{*}{$X_{i, t}$} & \multirow{2}{*}{$\begin{array}{c}\text { payoff } \\
\text { externality variables }\end{array}$} & pioneer age & 7146 & 1.59 & 3.37 & 0 & 18 \\
\hline & & & $\begin{array}{l}\text { lag branch density } \\
\text { (\#branches / population) }\end{array}$ & 7146 & $1.89 \mathrm{e}-06$ & $4.78 \mathrm{e}-06$ & 0.00 & $5.06 \mathrm{e}-05$ \\
\hline \multirow{5}{*}{$\begin{array}{c}\text { time } \\
\text { invariant } \\
\text { predictors }\end{array}$} & \multirow{5}{*}{$Z_{i}$} & \multirow{5}{*}{$\begin{array}{c}\text { Tehsil } \\
\text { characteristics } \\
\text { (source: Pakistan Census, } \\
1998 \text { ) }\end{array}$} & $\begin{array}{l}\text { population } \\
\text { (millions of people) }\end{array}$ & 7543 & 0.34 & 0.43 & 0.00 & 3.78 \\
\hline & & & $\begin{array}{l}\text { literacy } \\
(\text { literacy rate }(\%))\end{array}$ & 6935 & 31.23 & 15.75 & 1.89 & 76.00 \\
\hline & & & $\begin{array}{l}\text { kacha ratio } \\
\text { (\% of households living in } \\
\text { kacha housing) }\end{array}$ & 6935 & 47.74 & 25.98 & 0.44 & 98.77 \\
\hline & & & $\begin{array}{l}\text { rural ratio } \\
\text { (\% of households living in a } \\
\text { rural area) }\end{array}$ & 6935 & 83.93 & 19.68 & 0.00 & 100.00 \\
\hline & & & $\begin{array}{l}\text { gender literacy equity } \\
\text { (\% female literacy ratio/male } \\
\text { literacy ratio) }\end{array}$ & 6935 & 37.00 & 19.46 & 0.00 & 94.98 \\
\hline
\end{tabular}

\section{c) Control for cross-Tehsils heterogeneity in co-founding factors of entry}

It is of great importance, in order to identify herd behaviour properly, to control for Tehsil heterogeneity. Several MFIs may be collocated in one region merely because they have such homogeneous preferences that eventually, attracted by similar characteristics, 
they all end up in the same location. To avoid confusion, statistically speaking, between potential co-founding factors and herd behaviour, we have to control for the heterogeneity of these co-founding factors. In order to do so, we can use two means of control: 1) the introduction of demographic variables at the Tehsil level that will reflect differences in poverty level; or 2) the introduction of Tehsil fixed effects. Each of these means is explained below.

\section{- Tehsil poverty and remoteness characteristics: $Z_{i}$}

Tehsil invariant attributes $Z_{i}$ include the following variables: population; rural ratio (proportion of people living in rural areas); literacy (literacy rate of the population); kacha ratio (ratio of households living in a kacha house); and gender literacy equity (ratio in $\%$ of female literacy ratio to male literacy ratio - i.e. a ratio of $100 \%$ means that the literacy levels of males and females are the same). With the exception of population, Tehsil invariant attributes reflect the level of poverty, remoteness or the rural intensity of a Tehsil.

We expect MFIs to rely upon this information to take their location decisions since it allows them to set the level of poverty they want to reach out to (independently of what others have done). We expect $\beta_{2}$ to be negatively related with the likelihood of entry into a Tehsil because of financial concerns and uncertainty about financial performance, as mentioned in our theoretical framework.

It must be noted that as a control for heterogeneity (to identify real herd behaviour, as distinct from co-founding factors), the demographic variables we have at our disposal will not be sufficient. Faced with the lack of availability of other Tehsil features to control and with the likely existence of some unobserved or unobservable MFI 
preferences, we will take advantage of the panel structure of our dataset to include Tehsil fixed effect in our regressions.

\section{- Unobserved heterogeneity and Tehsil fixed effects: $u_{i}$}

Importantly, the implementation of our empirical methodology takes care to disentangle herding from correlated but independent location decisions -'spurious herding' (Bikhchandani \& Sharma, 2000) or ‘sequential correlation' (Zhang and Liu, 2012). Thus we introduced Tehsil fixed effects in our empirical analysis. While variables from the Pakistanis census may control for a part of the heterogeneous structural factors likely to commonly affect MFI choices, there may still remain some factors of heterogeneity (e.g. political risk, conflict areas or areas threatened by flooding) that are taken into account in the location decisions of MFIs but (for us) are unobservable (Manski, 1993; Villas-Boas \& Winer, 1999; Chintagunta 2001; Kuksov \& Villas-Boas, 2008). For instance, if two areas have exactly the same characteristics but one is situated in a war area and the other area (at peace) attracts all the branch openings, this must not be confused with any herding. Fortunately the panel structure of our dataset allows us to control for unobserved heterogeneity by using Tehsil fixed effects (Wooldridge, 2002) and thus to identify herd behaviour properly, ceteris paribus.

Statistically, the error term in the previous regression can be broken down as $\varepsilon_{i, t}=v_{i, t}+u_{i}$, where $v_{i, t}$ is orthogonal to other independent variables while $u_{i}$ represents unobserved Tehsil attributes. If $u_{i}$ consists of non-risky places in terms of flooding (for instance), it will be positively correlated with both the lagged number of MFIs $Y_{i, t-1}$ and the location decisions we wish to explain $y_{i, t}$.

More literally, this means that if we cannot control for flood risk because it is unobservable, and this risk is truly determinant of location decisions across Tehsils, the 
positive correlation between the lagged presence of MFIs $\left(Y_{i, t-1}\right)$ and new entries $\left(y_{i, t}\right)$ is not causal but emerges from this co-founding factor (the low risk of flood). This causes an 'errors in variables' type of endogeneity problem in estimating the coefficient $\alpha$ (Manski, Villas-Boas et Winer, 1999; Chintagunta, 2001; Kuksov \& Villas-Boas, 2008; Zhang \& Liu, 2012). Very importantly, the panel structure of our data set allows us to capture unobserved MFIs' co-founding factors of entry decisions by introducing Tehsil fixed effects (Wooldridge, 2002).

We then break down the term of error into ${ }^{u_{i}}$ and ${ }^{v_{i, t}}$ :

$$
y_{i, t}=\alpha Y_{i, t-1}+\beta_{1} X_{i, t}+\beta_{2} Z_{i}+u_{i}+v_{i, t}
$$

The effect of time-invariant Tehsil attributes $Z_{i}$ cannot be estimated with Tehsil fixed effects ${ }_{i}$ in the same regression because of the strict multi-collinearity between them. We then withdraw $Z_{i}$ and obtain:

$$
y_{i, t}=\alpha Y_{i, t-1}+\beta_{1} X_{i, t}+u_{i}+v_{i, t}
$$

We conclude that herd behaviour has occurred, to the extent that with this high level of control, $\alpha$ remains positive and significant.

\subsubsection{Rational versus irrational herding}

A herding behavior may occur even if MFIs do not engage in a rational observational learning of Tehsil quality (Bikhchandani, Hirshleifer \& Welch, 1992). This means that herding would be done regardless to the structural characteristics of the Tehsils and to the induced strength of the private information conveyed in previous location decisions. Equation (2') in itself cannot distinguish between irrational and rational herding, because the two mechanisms may be isomorphic in determining how many MFIs have entered 
over time. We draw on the cross-sectional variation in Tehsil attributes to distinguish irrational from rational herding.

If MFIs are simply replicating others' location decisions, they will be irresponsive to how others have arrived at such decisions. However, if MFIs are rational observational learners, their inferences from observing others' location decisions should be moderated by Tehsil richness attributes, since we assume that these signal less uncertainty and hence less need to learn from others. Reciprocally, herding should accelerate as Tehsil attributes exhibit poverty and remoteness features that we assume to be determinant of the MFIs' uncertainty. The rationale we describe here relies upon Zhang \& Liu's (2012) theoretical model. We then introduce the interaction terms between the lagged number of MFIs and Tehsil attributes:

$$
y_{i, t}=\alpha Y_{i, t-1}+\beta_{1} X_{i, t}+\beta_{2} Z_{i}+\beta_{3} Y_{i, t-1} * Z_{i}+v_{i, t}
$$

The cross-terms $Y_{i, t-1} * Z_{i}$ are used to capture the combined effect of Tehsil characteristics $\left(Z_{i}\right)$ and the earlier presence of MFIs within a Tehsil $Y_{i, t-1}$. In the rational herding scenario, it is assumed that MFIs feel great uncertainty about their future financial performance. Primarily, we expect that flowing from this uncertainty the main location decisions trend, independently of any herding, will be oriented towards relatively wealthy areas (more urbanised, built with brick and mortar, more literate, less traditional). However, because they have a strong social inclination, we also assumed that MFIs that possess reliable additional information on the opportunity to run sustainable microfinance activities in poorer places would be likely to do it. Under the hypothesis of rational herding, it is suggested that this additional information can be conveyed by the presence of earlier microfinance activities in a given place - this sends a positive signal. Thus, if a place exhibits both poverty features (fitting in with MFIs' 
social targeting) and the earlier presence of microfinance activities (solving the uncertainty problem by conveying positive information), then the likelihood of entry should be improved through rational herding.

Therefore, rational Herding occurs since earlier MFIs located in relatively poor areas mitigates or even reverse the main (negative) effects uncertainty may have on the entry likelihood of later MFIs in such places. In equation (3), under the rational herding hypothesis, $\beta_{3}$ should take a different sign from the coefficient of Tehsil attributes' main effects on the entry likelihood. With rational herding, for instance, if the coefficient of the variable literacy were positive in the regression analyzing the main effects literacy have on location decisions, then the coefficient of the cross-term (lag presence * literacy) should take a negative sign or be not significant in the regression analyzing rational herding.

- Main effects: pioneer entry likelihood (without the possibility of herding)

In the same way as Zhang and Liu (2012), we define the main effects of Tehsil attributes as the influence of Tehsil characteristics on the entry likelihood of pioneer institutions. We define a pioneer entry as a first branch opening in a given Tehsil. MFIs that perform a pioneer entry cannot base their decisions on any earlier MFIs within the area; thus their decision reflects perfectly the level of private information they have had, and which led them to enter into a Tehsil. Let's put $y_{i, \text { pioneer }}(c f$. the variable pioneer), the number of MFIs in year $\mathrm{t}$ that open the first microfinance branch within a Tehsil $i$. The following equation will be tested in order to arrive at the main effects of Tehsil attributes:

$$
y_{i, \text { pioneer }}=\alpha Z_{i}+v_{i}
$$

According to our theoretical framework, we expect pioneer entries to occur mainly in relatively well-developed areas. The idea is that pioneers' location decisions demarcate the 
bounds of microfinance within the country and thus constitute the basis for observation by following herding MFIs.

\subsection{Results}

\subsubsection{Preliminary analysis}

The left part of Table 2 reports the panel Poisson regression estimating Equation (2) (columns (1) to (6)). Each column from (1) to (5) presents a regression for each timeinvariant Tehsil attribute because we suspect that these attributes may exert overlapping effects on the dependent variable; this could explain why most of them display not significant effects in the regression in Column (6), which includes all features together. For instance, people in rural areas are generally less literate and the literacy gender gap is also likely to increase when the literacy rate is high; thus each of these indicators might be handled in similar ways in the decisional process of MFIs.

The possibly strong relation that exists between the covariates, i.e. multi-collinearity, is captured by the Variance Inflation Factor (VIF) (Zhang and Liu, 2012; Hair, Anderson, Tatham and Black, 2009). The VIF captures the strength of the relation between one covariate and the other covariates through the quality of the fit when regressing the former on the latter. The better the fit of the regression of one covariate on others, the more hazardous could be the interpretation of the coefficients of the latter when they are present with the former in the same regression.

The problem is that one covariate explained by the other ones could literally absorb the explanation power these other covariates might have regarding the dependent variable; this would tag the other covariates counter-intuitively as 'not significant' or even as carrying the opposite sign compared with what could have been intuitively expected. As a rule, we consider that the VIF of one of our variables within a regression should not 
exceed 10 for a consistent interpretation of the coefficients of this regression (Zhang \& Liu, 2012; Hair et al., 2013). In Regression (6), which integrates all Tehsils' features, not surprisingly, the higher VIF reaches 20.14.

Interestingly, taking each feature one-by-one allows us to make comparisons of the proper effects of each Tehsil feature and to notice, for instance, that the gender literacy equity is probably the most discriminating criterion for an MFI since the regression in Column (5) exhibits the highest pseudo-R-squared and since the coefficient of this variable in Column (6) remains highly significant - annihilating, incidentally, the explanation for other poverty characteristics such as the literacy ratio, the kacha ratio, and the rural ratio. However, these three latter features, taken individually in regressions in columns (2), (3), (4) respectively, exhibit the expected impact on MFIs' entry likelihood: a high literacy ratio (signalling a relatively well-developed Tehsil) increases the likelihood of an MFI entry; consistently, the opposite effect is observed with high rural intensity and kacha ratio.

As regards the regression in columns (1) to (5), including only one Tehsil time invariant regressor at a time, we can see that the coefficient of the lagged presence of microfinance (lag presence) in a Tehsil is positive and highly significant in every regression; this suggests that the presence of one or more MFIs increases the likelihood of subsequent entries. But at this stage, this does not provide any evidence of herd behaviour because of the omitted variable issue and a possible lack of control for Tehsil heterogeneity in the co-founding factors. In fact this only proves the presence of sequential correlation: MFIs might be spatially clustered in response to co-founding factors that we are not able to observe or measure.

Interestingly, however we can note already that through stronger control for Tehsil heterogeneity in co-founding factors in Regression (6) the herding variable (lag 
presence) is getting lower in comparison to regressions (1) to (5), but it is still strongly significant (p-value under the $1 \%$ risk threshold). This gives a first sign of how herding is statistically revealed, i.e. though lowered by controlling for more heterogeneity, the coefficient of the herding variable has to remain robustly positive and significant to be distinguished from a mere sequential correlation.

\subsubsection{Evidence of herding}

The results of the fixed-effect panel Poisson regression in Equation (2b) are reported on the right side of Table 2 (Column (7)). The coefficient of the lagged number of MFIs is still positive and strongly significant (p-value under the $1 \%$ risk threshold), as observed in regressions testing the sequential correlation. Therefore, this confirms the existence of herd behaviour: other things being equal, the likelihood that a new MFI will enter into a Tehsil increases significantly with the earlier presence of one or more MFIs.

Interestingly, in Equation (6) variables controlling for payoff externalities - i.e. the age of the incumbent pioneer MFI (pioneer age) and the lagged microfinance penetration (lag branches density) - respond in opposite ways: an already concentrated microfinance market seems to have a negative impact on MFIs' location decisions according to the negative and significant coefficient of the lagged branches density variable. This could have two possible explanations: either it could reflect a rather social inclination of MFIs that eventually prefer serving the underserved where microfinance penetration is low; or this may be based on competition concerns. Indeed, as shown in the empirical work of McIntosh et al. (2005), an increasing level of competition may provoke decline in the repayment performance. 
Table 2: Preliminary analysis - sequential correlation and herding

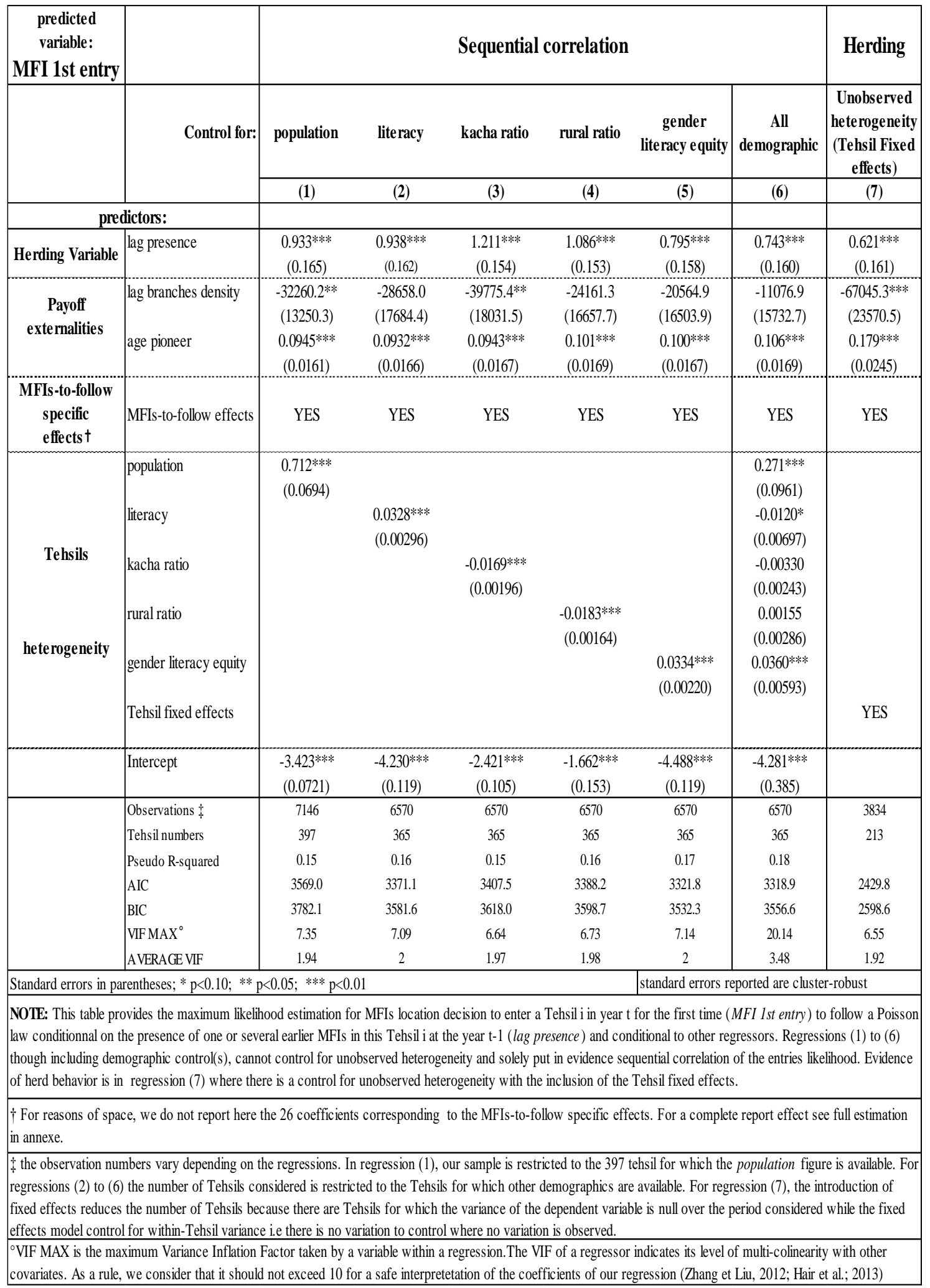

Conversely, the longevity of the incumbent pioneer(s) (age pioneer) has a positive and

significant impact on entry likelihood. We assumed that from a financial point of view, 
this could reflect the fact that the maturity of customers strengthens the probability of financial success for a new branch.

It is overall very complicated to distinguish which type of externality is more at stake in the MFI decision-maker's mind; but this is not the point of our work - the most important thing here is to provide a control for these externalities.

\subsubsection{Evidence of rational herding}

Table 3 reports on the impacts that Tehsil characteristics have on pioneer entry as put in Equation (4). This allows us to determine the main effect of Tehsil poverty on the entry likelihood of first entrant MFIs, regardless of the influence of earlier institutions within a place. As we assumed, the poorer a Tehsil appears to be, the less likely it is to be selected by an MFI. Pioneer entries are significantly more often located in urbanised areas, where the level of literacy is high for both male and female residents, and where dwelling conditions are rather good. In line with results presented in the previous section, these results confirm the momentum of MFIs' location decisions and will be used as our comparison basis for the identification of rational herding.

Table 4 reports the results of our rational herding test according to Equation (3). Regressions are Poisson regressions in which we have introduced interaction variables characterised by the multiplication of the lagged presence of microfinance activities (lag presence) by each Tehsil attribute. As we are still faced with an important multicollinearity problem between Tehsil attributes, we continue by reporting one regression for each interaction term. Moreover, to reduce multi-collinearity (which is likely to occur between lag presence and interaction regressors) we safely centre each term of the interaction variables (Aiken \& West, 1991). 
Table 3: pioneer entry - main effects of Tehsil characteristics

\begin{tabular}{|c|c|c|c|c|c|c|}
\hline \multirow{2}{*}{$\begin{array}{c}\text { Independent variable: } \\
\text { pioneer }\end{array}$} & \multicolumn{6}{|c|}{ Poisson regression } \\
\hline & \multicolumn{6}{|c|}{ pioneer entry: main effects of Tehsil characteristic } \\
\hline \multirow{2}{*}{$\begin{array}{c}\text { Predictor variables } \\
\text { population }\end{array}$} & (1) & (2) & (3) & (4) & (5) & (6) \\
\hline & $\begin{array}{c}0.550 * * * \\
(5.61)\end{array}$ & & & & & $\begin{array}{l}-0.0236 \\
(-0.14)\end{array}$ \\
\hline literacy & & $\begin{array}{l}0.0315 * * * \\
\quad(7.75)\end{array}$ & & & & $\begin{array}{l}0.0124 \\
(1.30)\end{array}$ \\
\hline kacha ratio & & & $\begin{array}{c}-0.0129 * * * \\
(-4.68)\end{array}$ & & & $\begin{array}{c}0.00211 \\
(0.55)\end{array}$ \\
\hline rural ratio & & & & $\begin{array}{c}-0.0147 * * * \\
(-5.79)\end{array}$ & & $\begin{array}{c}0.00360 \\
(0.84)\end{array}$ \\
\hline gender literacy equity & & & & & $\begin{array}{c}0.0267 * * * \\
(8.11)\end{array}$ & $\begin{array}{c}0.0233 * * * \\
(2.74)\end{array}$ \\
\hline intercept & $\begin{array}{c}-3.747 * * * \\
(-44.98)\end{array}$ & $\begin{array}{c}-4.637 * * * \\
(-26.29)\end{array}$ & $\begin{array}{c}-2.961 * * * \\
(-23.05)\end{array}$ & $\begin{array}{c}-2.344 * * * \\
(-11.47)\end{array}$ & $\begin{array}{c}-4.653 * * * \\
(-26.87)\end{array}$ & $\begin{array}{c}-5.323 * * * \\
(-8.43)\end{array}$ \\
\hline Observations & 7543 & 6935 & 6935 & 6935 & 6935 & 6935 \\
\hline$\left(\mathrm{N}^{\circ}\right.$ of Tehsil) & $(397)$ & $(365)$ & (365) & $(365)$ & $(365)$ & $(365)$ \\
\hline pseudo R-sq & 0.01 & 0.03 & 0.01 & 0.01 & 0.03 & 0.04 \\
\hline AIC & 2007.8 & 1810.8 & 1845.8 & 1841.1 & 1805.4 & 1810.7 \\
\hline $\mathrm{BIC}$ & 2021.7 & 1824.4 & 1859.4 & 1854.8 & 1819.1 & 1851.8 \\
\hline
\end{tabular}

$\mathrm{t}$ statistics in parentheses

$* \mathrm{p}<0.10 ; * * \mathrm{p}<0.05 " ; * * * \mathrm{p}<0.01$

As expected under the hypothesis of observational learning and rational herding, interaction variables take the opposite sign or are not significant in comparison with the main effects depicted in the literature, as previously verified in Table 3 when analysing pioneer locations. The most striking result of rational herding concerns the variable literacy (Column 2 in Table 4). The coefficient of the interaction variables (that combine the literacy rate ratio and the lagged presence of MFIs) is negative and significant at the $1 \%$ risk threshold, whereas both the theory and our previous regressions suggested that 
areas where people were more literate were more attractive. This means that the presence of MFIs in a weakly literate Tehsil reverses the prior negative influence of location in such a Tehsil. The same result holds for areas presenting a higher gender gap in the literacy rate (significance at the 5\% risk threshold) and for rural areas (significance at the $10 \%$ risk threshold). The influence of the kacha ratio, indicative of the quality of housing in Tehsils, changes from a negative main effect on the entry likelihood of MFIs to a not significant impact when taking into account the earlier presence of MFIs.

Such herding seems to operate as a reversing or neutralizing effect on the general tendency of MFIs to prefer being located in safer areas at the expense of the poorest rural ones. Those results validate the hypothesis of observational learning and the occurrence of rational herding towards the poor. 
Table 4: Rational herding

\begin{tabular}{|c|c|c|c|c|c|c|c|}
\hline & & \multicolumn{6}{|c|}{ Poiss on regressions } \\
\hline \multirow{3}{*}{\multicolumn{2}{|c|}{ predicted: MFI 1st entry }} & \multicolumn{6}{|c|}{ Rational herding } \\
\hline & & population & literacy & kacha ratio & rural ratio & $\begin{array}{l}\text { gender } \\
\text { literacy }\end{array}$ & all \\
\hline & & $(1)$ & $(2)$ & (3) & $(4)$ & (5) & $(6)$ \\
\hline \multicolumn{8}{|c|}{ predictors: } \\
\hline $\begin{array}{l}\text { he rding variable } \\
\text { (main effect } \mathrm{A} \text { ) }\end{array}$ & lag presence & $\begin{array}{c}1.109 * * * \\
(6.77)\end{array}$ & $\begin{array}{c}1.272^{* * * *} \\
(7.48)\end{array}$ & $\begin{array}{c}1.195^{* * * *} \\
(7.36)\end{array}$ & $\begin{array}{c}1.177^{* * * *} \\
(7.36)\end{array}$ & $\begin{array}{c}1.010^{* * * *} \\
(5.53)\end{array}$ & $\begin{array}{c}0.989 * * * \\
(5.18)\end{array}$ \\
\hline $\begin{array}{c}\text { payoff } \\
\text { externalities }\end{array}$ & $\begin{array}{l}\text { lag branches density } \\
\text { age pioneer }\end{array}$ & $\begin{array}{c}-42536.0^{* * * *} \\
(-2.74) \\
0.0882^{* * * *} \\
(4.77)\end{array}$ & $\begin{array}{c}-35805.3^{* *} \\
(-2.05) \\
0.0861^{* k *} \\
(4.62)\end{array}$ & $\begin{array}{c}-39636.7^{* *} \\
(-2.29) \\
0.0950^{* * *} \\
(4.98)\end{array}$ & $\begin{array}{c}-27727.5 \\
(-1.62) \\
0.0969 * * * \\
(5.05)\end{array}$ & 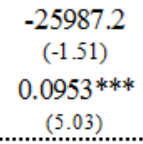 & 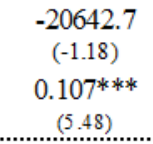 \\
\hline $\begin{array}{l}\text { MiFis-to-follow } \\
\text { hete roge ne ity } \\
\text { effects } †\end{array}$ & MFIs-to-follow effects & YES & YES & YES & YES & YES & YES \\
\hline $\begin{array}{c}\text { Tehs il } \\
\text { characte ristics } \\
\text { (main effect } B \text { ) }\end{array}$ & $\begin{array}{l}\text { population } \\
\text { literacy } \\
\text { kacha ratio } \\
\text { rural ratio } \\
\text { gender literacy equity }\end{array}$ & $\begin{array}{l}0.812^{* * * *} \\
(11.36)\end{array}$ & $\begin{array}{l}0.0365^{* * * *} \\
(11.14)\end{array}$ & $\begin{array}{c}-0.0168 * * * * \\
(-7.58)\end{array}$ & $\begin{array}{c}-0.0196 * * * * \\
(-10.18)\end{array}$ & $\begin{array}{c}0.0344^{* * * *} \\
(12.81)\end{array}$ & $\begin{array}{c}0.259^{* * *} \\
(2.07) \\
0.00000305 \\
(0.00) \\
-0.00163 \\
(-0.53) \\
0.00332 \\
(1.01) \\
0.0312^{* * *} \\
(4.64)\end{array}$ \\
\hline \multirow[t]{3}{*}{$\begin{array}{l}\text { inte raction } \\
\text { variables } \\
(\mathbf{A} * \mathbf{B})\end{array}$} & $\begin{array}{l}\text { lag presence } * \text { population } \\
\text { lag presence } * \text { literacy } \\
\text { lag presence } * \text { kacha ratio } \\
\text { lag presence } * \text { rural ratio } \\
\text { lag presence } * \text { gender literacy } \\
\text { equity }\end{array}$ & $\begin{array}{c}-0.423^{* * * *} \\
(-3.10)\end{array}$ & $\begin{array}{c}-0.0274 * * * * \\
(-4.24)\end{array}$ & $\begin{array}{c}-0.00118 \\
(-0.27)\end{array}$ & $\begin{array}{l}0.00601 * \\
(1.67)\end{array}$ & $\begin{array}{c}-0.0116^{* *} \\
(-2.11)\end{array}$ & $\begin{array}{c}-0.0215 \\
(-0.10) \\
-0.0526^{* * * *} \\
(-3.69) \\
-0.0154^{* * *} \\
(-2.51) \\
-0.0102^{*} \\
(-1.69) \\
0.00420 \\
(0.31)\end{array}$ \\
\hline & Constant & $\begin{array}{c}-3.483^{* * * *} \\
(-44.08)\end{array}$ & $\begin{array}{c}-4.421 * * * * \\
(-29.17)\end{array}$ & $\begin{array}{c}-2.423^{* * * *} \\
(-21.57) \\
\end{array}$ & $\begin{array}{c}-1.575^{* * * *} \\
(-9.82) \\
\end{array}$ & $\begin{array}{c}-4.566^{* * * *} \\
(-30.38)\end{array}$ & $\begin{array}{c}-4.746^{* k * *} \\
(-9.45)\end{array}$ \\
\hline & $\begin{array}{l}\text { Observations numbers } \ddagger \\
\text { Tehsil numbers } \\
\text { Pseudo R-squared } \\
\text { AIC } \\
\text { BIC } \\
\text { VIF MAX } \\
\text { A VERAGE VIF } \\
\end{array}$ & $\begin{array}{c}7146 \\
397 \\
0.16 \\
3561.7 \\
3781.7 \\
7.82 \\
2 \\
\end{array}$ & $\begin{array}{c}6570 \\
365 \\
0.17 \\
3355.1 \\
3572.4 \\
6.71 \\
1.98 \\
\end{array}$ & $\begin{array}{c}6570 \\
365 \\
0.15 \\
3409.4 \\
3626.7 \\
7.57 \\
2.02 \\
\end{array}$ & $\begin{array}{c}6570 \\
365 \\
0.16 \\
3387.5 \\
3604.8 \\
6.92 \\
2 \\
\end{array}$ & $\begin{array}{c}6570 \\
365 \\
0.18 \\
3319.4 \\
3536.7 \\
7.89 \\
2.04 \\
\end{array}$ & $\begin{array}{c}6570 \\
365 \\
0.18 \\
3305.8 \\
3577.4 \\
23.72 \\
4.06 \\
\end{array}$ \\
\hline \multicolumn{3}{|c|}{ Standard errors in parentheses; ${ }^{*} \mathrm{p}<0.10 ;{ }^{* *} \mathrm{p}<0.05 ;{ }^{* * *} \mathrm{p}<0.01$} & \multicolumn{5}{|c|}{ Standard errors reported are clu ster-robust } \\
\hline \multicolumn{8}{|c|}{$\begin{array}{l}\text { NOTE: This table provides the maximum likelihood estimation for MFIs location decision to enter a Tehsil i in y ear t for the first time (MFI } 1 \text { st entry) to } \\
\text { follow a Poisson law (conditional to our regressors). The rule for concluding to a rational herding is the rev ersed sign of the coefficient of an interaction } \\
\text { variable (A * B) that is the combined effect of the lag presence (A) and one Tehsil characteristic (B) in comp aris on with the main effects of Tehsil } \\
\text { characteristics put in evidence in the previous table analysing pioneer entries. }\end{array}$} \\
\hline
\end{tabular}




\section{4- Conclusion}

In this paper beyond the simple analysis of where MFIs prefers to be located, we investigated and find evidence that MFIs herded with each other within Pakistan. Most interestingly, we found out that a significant part of this herding behavior is rational since it has a significant moderating effect on the uncertainty that weigh on the willingness of MFIs to be in poorer, more rural areas. The Zhang \& Liu's (2012) methodology has allowed us to verify that the presence of one or several MFIs in a Tehsil moderates the negative influence of poverty and remoteness on MFIs willingness to open a new branch. This latter result has great implications on the way we can understand how microfinance activities expand across a country. On one hand, rational herding may predict beneficial effects i.e. an improved penetration of MFIs in adverse areas. On the other hand, however, it poses a problem of regions that could remain persistently isolated from MFIs activities.

More generally, identifying a rational herding of MFIs shed light on the great uncertainty faced by MFIs and emphasizes more than ever the great role played by pioneer institutions that map out the way toward poorer markets to subsequent ones. In a way, the beneficial impact on poverty of a decision taken by one MFI may be multiplied by the number of others MFIs that would learn from this decision.

Our result of rational herding toward the poor has also obvious implications in the debate on whether microfinance reaches the poorest. Especially, it provides a refreshing argument that goes in the sense of the Microfinance Promise (Morduch 1999) since it rather supports the existence of a "commitment (of institutions) to serving clients that have been excluded from the formal banking sector". Following Morduch, an important literature has discussed the question 
of how this commitment could be conciliated (or not) with increasing requirements of a financial performance ${ }^{6}$.

In this context, newly, our result of rational herding suggests therefore that information matters and that interestingly, through this behavior, MFIs seem to show a real willingness to overcome this barrier in order most likely to fit their social mission. The 'tension between meeting social goals and maximizing financial performance' (Cull, Demirgüc-Kunt and Morduch, 2009) that we argued existing ex-ante in MFIs location decisions seems to be alleviated when tangible and reliable information are provided to them.

\section{References:}

Abrahamson, E., \& Rosenkopf, L. (1993). Institutional and competitive bandwagons: Using mathematical modeling as a tool to explore innovation diffusion. Academy of management review, 18(3), 487-517.

Aghion, P., Caroli, E., \& Garcia-Penalosa, C. (1999). Inequality and economic growth: the perspective of the new growth theories. Journal of Economic literature, 1615-1660.

Aiken, L. S., \& West, S. G. (1991). Multiple regression: Testing and interpreting interactions. Sage.

Amin, S., Rai, A. S., \& Topa, G. (2003). Does microcredit reach the poor and vulnerable? Evidence from northern Bangladesh. Journal of Development Economics, 70(1), 59-82.

\footnotetext{
${ }^{6}$ See for instance Mersland and Strom (2009), Cull, Demirgüc-Kunt and Morduch, 2007 and 2009; Hermes, Lensink and Meesters (2011);
} 
Banerjee, A. V. (1992). A simple model of herd behavior. The Quarterly Journal of Economics, 797-817.

Banerjee, A. V., \& Duflo, E. (2003). Inequality and growth: what can the data say? Journal of economic growth, 8(3), 267-299.

Banerjee, A. V., \& Duflo, E. (2005). Chapter 7 Growth Theory through the Lens of Development Economics. In Philippe Aghion and Steven N. Durlauf (Éd.), Handbook of Economic Growth (Vol. Volume 1, Part A, p. 473- 552).

Basu, P., \& Srivastava, P. (2005). Scaling-up microfinance for India's rural poor. World Bank Policy Research Working Paper, (3646).

Belderbos, R., Olffen, W. V., \& Zou, J. (2011). Generic and specific social learning mechanisms in foreign entry location choice. Strategic Management Journal, 32(12), $1309-1330$.

Bikhchandani, S., Hirshleifer, D., \& Welch, I. (1992). A Theory of Fads, Fashion, Custom, and Cultural Change as Informational Cascades. Journal of Political Economy, 100(5), 992- 1026.

Bikhchandani, S., \& Sharma, S. (2000). Herd behavior in financial markets. IMF Staff papers, 279-310. 
Brandenburger, A., \& Polak, B. (1996). When managers cover their posteriors: Making the decisions the market wants to see. The RAND Journal of Economics, 523-541.

Cai, H., Chen, Y., \& Fang, H. (2009). « Observational Learning: Evidence from a Randomized Natural Field Experiment ». The American economic review 99 (3): 864- 82.

Chang, A., Chaudhuri, S., \& Jayaratne, J. (1997b). Rational herding and the spatial clustering of bank branches: an empirical analysis. http://www.newyorkfed.org/research/staff_reports/research_papers/9724.pdf

Chevalier, J., \& Ellison, G. (1999). Career concerns of mutual fund managers. The Quarterly Journal of Economics, 114(2), 389-432.

Chintagunta, P. K. (2001). Endogeneity and heterogeneity in a probit demand model: Estimation using aggregate data. Marketing Science, 20(4), 442-456.

Claessens, S., \& Perotti, E. (2007). Finance and inequality: Channels and evidence. Journal of Comparative Economics, 35(4), 748-773.

Copestake, J. (2007). Mainstreaming microfinance: social performance management or mission drift? World Development, 35(10), 1721-1738.

Cull, R., Demirgüc-Kunt, A., \& Morduch, J. (2009). Microfinance Trade-Offs: Regulation, Competition and Financing. The Handbook of Microfinance. 
Cull, R., Morduch, J., \& others. (2007).Financial performance and outreach: a global analysis of leading microbanks*. The Economic Journal, 117(517), F107-F133.

Desai, B. M., \& Mellor, W. J. (1993). Institutional finance for agricultural development: an analytical survey of critical issues. Intl Food Policy Res Inst.

Devenow, A., \& Welch, I. (1996). Rational herding in financial economics. European Economic Review, 40(3), 603-615.

DiMaggio, P. J., \& Powell, W. W. (1983). The iron cage revisited: Institutional isomorphism and collective rationality in organizational fields. American sociological review, 147-160.

Drehmann, M., Oechssler, J., \& Roider, A. (2007). Herding with and without payoff externalities - an internet experiment. International Journal of Industrial Organization, 25(2), 391- 415. doi:10.1016/j.ijindorg.2006.04.016

Fruttero, A., \& Gauri, V. (2005). The Strategic Choices of NGOs: Location Decisions in Rural Bangladesh1. Journal of Development Studies, 41(5), 759- 787. doi:10.1080/00220380500145289

Gimeno, J., Hoskisson, R. E., Beal, B. D., \& Wan, W. P. (2005). Explaining the clustering of international expansion moves: A critical test in the US telecommunications industry. Academy of Management Journal, 48(2), 297-319. 
Godquin, M. (2004). Microfinance repayment performance in Bangladesh: How to improve the allocation of loans by MFIs. World Development, 32(11), 1909-1926.

Greenwood, J., \& Jovanovic, B. (1989). Financial development, growth, and the distribution of income. National Bureau of Economic Research.

Hahn, E. D., Doh, J., \& Bunyaratavej, K. (2009). The evolution of risk in information systems offshoring: the impact of home country risk, firm learning, and competitive dynamics. Management Information Systems Quarterly, 33(3), 12.

Hair, J. F., Jr., R. E. Anderson, R. L. Tatham, and W. C. Black (2009), Multivariate Data Analysis, 7th ed. Macmillan, New York.

Hartarska, V. (2005). Governance and performance of microfinance institutions in Central and Eastern Europe and the newly independent states. World development, 33(10), 16271643.

Head, K., Mayer, T., \& Ries, J. (2002). Revisiting oligopolistic reaction: are decisions on foreign direct investment strategic complements? Journal of Economics \& Management Strategy, 11(3), 453-472.

Henisz, W. J., \& Delios, A. (2001). Uncertainty, Imitation, and Plant Location: Japanese Multinational Corporations, 1990-1996. Administrative science quarterly, 46(3), 443475. 
Hermes, N., Lensink, R., \& Meesters, A. (2011). Outreach and efficiency of microfinance institutions. World Development, 39(6), 938-948.

Hirshleifer, D., \& Hong Teoh, S. (2003). Herd Behaviour and Cascading in Capital Markets: a Review and Synthesis. European Financial Management, 9(1), 25- 66. doi:10.1111/1468-036X.00207

Johnston, D., \& Morduch, J. (2008). The unbanked: evidence from Indonesia. The World Bank Economic Review, 22(3), 517-537.

Katz, M. L., \& Shapiro, C. (1985). Network externalities, competition, and compatibility. The American economic review, 424-440.

Khandker, S. R., Khalily, M. B., \& Khan, Z. H. (1995). Grameen Bank: performance and sustainability (Vol. 306). World Bank Publications.

King, R. G., \& Levine, R. (1993). Finance, entrepreneurship and growth. Journal of Monetary economics, 32(3), 513-542.

Kuksov, D., \& Villas-Boas, J. M. (2008). Endogeneity and individual consumer choice. Journal of Marketing Research, 45(6), 702-714.

Lapenu, C., \& Zeller, M. (2001). Distribution, growth, and performance of microfinance institutions in Africa, Asia, and Latin America. Retrieved from http://www.ifpri.org/sites/default/files/publications/fcndp114.pdf 
Manski, C. F. (1993). Identification of endogenous social effects: The reflection problem. The review of economic studies, 60(3), 531-542.

McIntosh, C., de Janvry, A., \& Sadoulet, E. (2005). How Rising Competition Among Microfinance Institutions Affects Incumbent Lenders*. The Economic Journal, 115(506),

Mersland, R., \& Øystein Strøm, R. (2009). Performance and governance in microfinance institutions. Journal of Banking \& Finance, 33(4), 662-669.

Morduch, J. (1999). The Microfinance Promise. Journal of Economic Literature, 37(4), $1569-1614$.

Pagano, M. (1993). Financial markets and growth: an overview. European economic review, 37(2), 613-622.

Park, A., \& Ren, C. (2001). Microfinance with Chinese characteristics. World Development, 29(1), 39-62.

Ravallion, M. (2001). Growth, inequality and poverty: looking beyond averages. World development, 29(11), 1803-1815.

Scharfstein, D. S., \& Stein, J. C. (1990). Herd Behavior and Investment. The American Economic Review, 80(3), 465- 479.

Sharma, M., \& Zeller, M. (1997). Repayment performance in group-based credit programs in Bangladesh: An empirical analysis. World development, 25(10), 1731-1742. 
Sharma, M., \& Zeller, M. (1999). Placement and outreach of group-based credit organizations: The cases of ASA, BRAC, and PROSHIKA in Bangladesh. World Development, 27(12), 2123-2136.

Shaw, J. (2004). Microenterprise occupation and poverty reduction in microfinance programs: Evidence from Sri Lanka. World Development, 32(7), 1247-1264.

Suire, R., \& Vicente, J. (2009). Why do some places succeed when others decline? A social interaction model of cluster viability. Journal of Economic Geography, 9(3), 381404.

Villas-Boas, J. M., \& Winer, R. S. (1999). Endogeneity in brand choice models. Management Science, 45(10), 1324-1338.

Welch, I. (1992). Sequential sales, learning, and cascades. The Journal of finance, 47(2), $695-732$.

Wooldridge, J. M. (1999). Distribution-free estimation of some nonlinear panel data models. Journal of Econometrics, 90(1), 77-97.

Wooldridge, J. M. (2002). Econometric analysis of cross section and panel data. The MIT press. 
World Bank, (2005a). Empowering People by Transforming Institutions: A

Strategy and Implementation Plan for Social Development in Bank Operations.

Washington, DC: World Bank.

World Bank (2000 - 2001). World Development Report on Poverty and Development, Washington DC, World Bank.

Yaron, J. (1994). What makes rural finance institutions successful? The World Bank Research Observer, 9(1), 49-70.

Yunus, Muhammad. 2008. "What Is Microcredit?” Grameen Bank, Dhaka. from www.grameeninfo.org/bank/WhatisMicrocredit.htm.

Zhang, J., \& Liu, P. (2012). Rational herding in microloan markets. Management science, $58(5), 892-912$. 


\section{Appendix}

Table A1: MFIs' preferences

\begin{tabular}{|c|c|c|c|c|c|}
\hline \multicolumn{6}{|c|}{ MFIs preferences } \\
\hline MFI id \# & $\begin{array}{c}\text { social } \\
\text { targeting }\end{array}$ & $\begin{array}{l}\text { subsidized } \\
\text { funding* } \\
\text { (grants or } \\
\text { donations) }\end{array}$ & $\begin{array}{l}\text { charged } \\
\text { funding* } \\
\text { (loans or } \\
\text { equity) }\end{array}$ & $\begin{array}{l}\text { sus tainability } \\
\text { explicitely } \\
\text { reported }\end{array}$ & $\begin{array}{c}\text { PPAF funding } \\
\text { (grant or } \\
\text { loans) }\end{array}$ \\
\hline 1 & yes & yes & no & no & no \\
\hline 2 & yes & no & yes & no & yes \\
\hline 3 & yes & yes & yes & yes & yes \\
\hline 4 & yes & no & yes & no & yes \\
\hline 5 & yes & yes & yes & no & yes \\
\hline 6 & yes & yes & yes & yes & yes \\
\hline 7 & yes & yes & yes & yes & yes \\
\hline 8 & yes & yes & yes & yes & no \\
\hline 9 & yes & no & yes & yes & yes \\
\hline 10 & yes & yes & yes & yes & no \\
\hline $11 * *$ & yes & yes & yes & no & no \\
\hline $12 * *$ & yes & yes & yes & yes & yes \\
\hline 13 & yes & yes & yes & no & yes \\
\hline 14 & yes & yes & yes & yes & yes \\
\hline 15 & yes & yes & yes & yes & yes \\
\hline $16^{* *}$ & yes & yes & yes & yes & no \\
\hline 17 & yes & yes & yes & yes & yes \\
\hline 18 & yes & yes & yes & yes & yes \\
\hline $19 * *$ & yes & No & yes & yes & no \\
\hline 20 & yes & NA*** & $\mathrm{NA}^{* * *}$ & yes & yes \\
\hline 21 & yes & No & yes & yes & yes \\
\hline 22 & yes & yes & yes & yes & yes \\
\hline 23 & yes & yes & yes & yes & yes \\
\hline 24 & yes & yes & yes & yes & no \\
\hline $25^{* *}$ & yes & yes & yes & yes & yes \\
\hline 26 & yes & yes & yes & yes & yes \\
\hline
\end{tabular}

* Currently source of funding and/or seeking for it. source: mixmarket.org

**Microfinance bank

***This MFI reported no information about its funding source nor on the mix market either on its website 
Table A2: Preliminary analysis - sequential correlation and herding including MFIs-to-

\section{follow effects details}

\begin{tabular}{|c|c|c|c|c|c|c|c|c|}
\hline \multirow{2}{*}{\multicolumn{2}{|c|}{ predicted: MFI 1st entry }} & \multicolumn{7}{|c|}{ Poisson regressions } \\
\hline & & \multicolumn{6}{|c|}{ Sequential correlation } & \multirow{2}{*}{\begin{tabular}{|c|} 
Herding \\
$\begin{array}{c}\text { Unobserved } \\
\text { heterogeneity } \\
\text { (Tehsil Fixed } \\
\text { effects) }\end{array}$ \\
\end{tabular}} \\
\hline & \multirow[t]{2}{*}{ Control for: } & population & literacy & kacha ratio & rural ratio & $\begin{array}{c}\text { gender lite racy } \\
\text { equity }\end{array}$ & $\begin{array}{c}\text { All } \\
\text { demographic }\end{array}$ & \\
\hline & & (1) & (2) & (3) & (4) & (5) & (6) & (7) \\
\hline \multicolumn{9}{|c|}{ predictors: } \\
\hline Herding Variable & lag presence & $\begin{array}{c}0.933^{* * * * *} \\
(0.165)\end{array}$ & $\begin{array}{c}0.938 * * * * \\
(0.162)\end{array}$ & $\begin{array}{c}1.211^{* * * *} \\
(0.154)\end{array}$ & $\begin{array}{c}1.086 * * * \\
(0.153)\end{array}$ & $\begin{array}{c}0.795 * * * \\
(0.158)\end{array}$ & $\begin{array}{c}0.743 * * * \\
(0.160)\end{array}$ & $\begin{array}{c}0.621 * * * \\
(0.161)\end{array}$ \\
\hline Payoff externalities & $\begin{array}{l}\text { lag branches density } \\
\text { age pionneer }\end{array}$ & $\begin{array}{c}-32260.2 * * \\
(13250.3) \\
0.0945 * * * \\
(0.0161)\end{array}$ & $\begin{array}{l}-28658.0 \\
(17684.4) \\
0.0932 * * * \\
(0.0166)\end{array}$ & $\begin{array}{c}-39775.4 * * \\
(18031.5) \\
0.0943 * * * \\
(0.0167)\end{array}$ & $\begin{array}{l}-24161.3 \\
(16657.7) \\
0.101 * * * \\
(0.0169)\end{array}$ & $\begin{array}{l}-20564.9 \\
(16503.9) \\
0.100 * * * \\
(0.0167)\end{array}$ & $\begin{array}{l}-11076.9 \\
(15732.7) \\
0.106 * * * \\
(0.0169)\end{array}$ & $\begin{array}{c}-67045.3 * * * \\
(23570.5) \\
0.179 * * * \\
(0.0245)\end{array}$ \\
\hline MFIs-to-follow & $\begin{array}{l}\text { lag MFI_1 } \\
\text { lag MFI_2 } \\
\text { lag MFI_3 } \\
\text { lag MFI_4 } \\
\text { lag MFI_5 } \\
\text { lag MFI_6 } \\
\text { lag MFI_7 } \\
\text { lag MFI_8 } \\
\text { lag MFI_9 } \\
\text { lag MFI_10 } \\
\text { lag MFI_11 } \\
\text { lag MFI_12 } \\
\text { lag MFI_13 } \\
\text { lag MFI_14 } \\
\text { lag MFI_15 } \\
\text { lag MFI_16 } \\
\text { lag MFI_17 } \\
\text { lag MFI_18 } \\
\text { lag MFI_19 } \\
\text { lag MFI_20 } \\
\text { lag MFI_21 } \\
\text { lag MFI_22 } \\
\text { lag MFI_23 } \\
\text { lag MFI_24 } \\
\text { lag MFI_25 } \\
\text { lag MFI_26 }\end{array}$ & $\begin{array}{c}-0.155 \\
(0.302) \\
-0.672^{* * *} * \\
(0.178) \\
0.261 \\
(0.213) \\
-0.458^{*} \\
(0.258) \\
0.694 \\
(0.451) \\
-1.537^{* * *} \\
(0.590) \\
-0.0436 \\
(0.473) \\
-0.0389 \\
(0.178) \\
-0.0832 \\
(0.326) \\
0.175 \\
(0.159) \\
-0.372^{*} \\
(0.224) \\
0.440^{* * *} \\
(0.123) \\
-0.943^{* * *} \\
(0.196) \\
0.495 \\
(0.341) \\
0.686 \\
(0.461) \\
0.246 \\
(0.288) \\
0.0198 \\
(0.159) \\
-0.657^{* * *} \\
(0.301) \\
-0.459 \\
(0.650) \\
1.025^{* * *} \\
(0.257) \\
-0.0753 \\
(0.194) \\
-0.706 \\
(0.448) \\
0.616 \\
(0.419) \\
-0.0567 \\
(0.317) \\
0.0951 \\
(0.260) \\
-0.116 \\
(0.224)\end{array}$ & $\begin{array}{c}-0.0879 \\
(0.268) \\
-0.542^{* * *} * \\
(0.185) \\
0.422^{* * *} \\
(0.205) \\
-0.475^{*} \\
(0.244) \\
0.706 \\
(0.494) \\
-0.796 \\
(0.532) \\
0.105 \\
(0.536) \\
-0.0976 \\
(0.174) \\
-0.0551 \\
(0.302) \\
0.250 \\
(0.153) \\
-0.559^{* *} \\
(0.222) \\
0.376^{* * *} \\
(0.129) \\
-1.103^{* * *} \\
(0.216) \\
0.510 \\
(0.328) \\
0.513 \\
(0.493) \\
-0.0906 \\
(0.313) \\
-0.236 \\
(0.163) \\
-0.700^{* * *} \\
(0.315) \\
-1.086^{*} \\
(0.660) \\
1.011^{* * *} \\
(0.259) \\
-0.235 \\
(0.208) \\
-0.521 \\
(0.453) \\
0.299 \\
(0.421) \\
0.0924 \\
(0.339) \\
0.213 \\
(0.268) \\
0.134 \\
(0.192)\end{array}$ & $\begin{array}{c}-0.0363 \\
(0.265) \\
-0.685 * * * \\
(0.187) \\
0.414 * * \\
(0.209) \\
-0.389 \\
(0.239) \\
0.531 \\
(0.453) \\
-0.526 \\
(0.499) \\
0.247 \\
(0.548) \\
0.0614 \\
(0.172) \\
-0.0788 \\
(0.311) \\
0.183 \\
(0.156) \\
-0.541^{* *} \\
(0.223) \\
0.367 * * * \\
(0.131) \\
-1.167 * * * \\
(0.212) \\
0.379 \\
(0.328) \\
0.621 \\
(0.489) \\
-0.0612 \\
(0.309) \\
-0.240 \\
(0.170) \\
-0.908 * * * \\
(0.323) \\
-1.079 * \\
(0.647) \\
0.952 * * * \\
(0.272) \\
-0.174 \\
(0.212) \\
-0.462 \\
(0.461) \\
0.362 \\
(0.422) \\
0.0636 \\
(0.338) \\
0.295 \\
(0.266) \\
0.294 \\
(0.194)\end{array}$ & $\begin{array}{c}0.0352 \\
(0.264) \\
-0.819^{* * *} * \\
(0.180) \\
0.410^{* *} \\
(0.200) \\
-0.514^{* *} \\
(0.233) \\
0.714 * \\
(0.403) \\
-0.995^{*} \\
(0.509) \\
-0.0139 \\
(0.484) \\
-0.186 \\
(0.170) \\
-0.254 \\
(0.298) \\
0.301^{* *} \\
(0.149) \\
-0.394^{*} \\
(0.219) \\
0.322^{* * *} * \\
(0.124) \\
-1.000^{* * *} * \\
(0.201) \\
0.419 \\
(0.338) \\
0.356 \\
(0.515) \\
0.0161 \\
(0.298) \\
0.0163 \\
(0.159) \\
-0.658^{* * *} \\
(0.319) \\
-1.164 * \\
(0.634) \\
0.933^{*} * * \\
(0.259) \\
-0.476^{* *} \\
(0.201) \\
-0.546 \\
(0.466) \\
0.763 * \\
(0.428) \\
-0.252 \\
(0.333) \\
-0.0287 \\
(0.247) \\
-0.0878 \\
(0.204)\end{array}$ & $\begin{array}{c}-0.0219 \\
(0.261) \\
-0.700^{* * *} \\
(0.182) \\
0.474^{* *} \\
(0.197) \\
-0.457^{*} \\
(0.238) \\
0.696 \\
(0.453) \\
-1.049^{* *} \\
(0.527) \\
0.000535 \\
(0.522) \\
-0.111 \\
(0.170) \\
-0.302 \\
(0.298) \\
0.158 \\
(0.151) \\
-0.478^{*} * \\
(0.213) \\
0.354^{*} * * \\
(0.126) \\
-0.946^{*} * * \\
(0.208) \\
0.447 \\
(0.341) \\
0.381 \\
(0.500) \\
-0.0985 \\
(0.310) \\
-0.313^{*} \\
(0.163) \\
-0.902^{*} * * \\
(0.324) \\
-1.034 \\
(0.636) \\
1.082^{*} * * \\
(0.262) \\
-0.104 \\
(0.207) \\
-0.241 \\
(0.476) \\
0.338 \\
(0.450) \\
0.0374 \\
(0.341) \\
0.0351 \\
(0.253) \\
-0.0188 \\
(0.186)\end{array}$ & $\begin{array}{c}-0.0521 \\
(0.273) \\
-0.771^{* * *} * \\
(0.184) \\
0.427 * * \\
(0.201) \\
-0.446 * \\
(0.239) \\
0.656 \\
(0.424) \\
-1.390^{* *} \\
(0.555) \\
-0.0108 \\
(0.491) \\
-0.0841 \\
(0.172) \\
-0.358 \\
(0.303) \\
0.0565 \\
(0.155) \\
-0.427 * * \\
(0.212) \\
0.342^{* * *} * \\
(0.125) \\
-0.923 * * * \\
(0.208) \\
0.392 \\
(0.347) \\
0.383 \\
(0.486) \\
-0.0917 \\
(0.305) \\
-0.304 * \\
(0.168) \\
-0.984^{*} * * \\
(0.325) \\
-0.816 \\
(0.633) \\
1.083^{*} * * \\
(0.265) \\
-0.0459 \\
(0.213) \\
-0.342 \\
(0.481) \\
0.351 \\
(0.451) \\
-0.0584 \\
(0.356) \\
-0.0576 \\
(0.246) \\
-0.175 \\
(0.199)\end{array}$ & $\begin{array}{c}-0.0517 \\
(0.180) \\
-1.678^{* * *} * \\
(0.354) \\
-0.0142 \\
(0.191) \\
-0.326 \\
(0.233) \\
0.626 * \\
(0.380) \\
-0.393 \\
(0.320) \\
0.364 \\
(0.595) \\
-0.329 * \\
(0.192) \\
0.250 \\
(0.317) \\
0.109 \\
(0.174) \\
-0.485 * * \\
(0.242) \\
0.147 \\
(0.160) \\
-1.916 * * * \\
(0.294) \\
0.109 \\
(0.368) \\
0.316 \\
(0.441) \\
0.126 \\
(0.286) \\
-0.726^{* * * *} \\
(0.207) \\
-2.315 * * * \\
(0.711) \\
-0.913^{*} * * * \\
(0.306) \\
0.854 * * * \\
(0.197) \\
-0.832^{* * * *} \\
(0.273) \\
-0.550 \\
(0.406) \\
-0.177 \\
(0.376) \\
-0.315 \\
(0.500) \\
0.196 \\
(0.262) \\
0.0970 \\
(0.203)\end{array}$ \\
\hline heterogeneity & $\begin{array}{l}\text { population } \\
\text { literacy } \\
\text { kacha ratio } \\
\text { rural ratio } \\
\text { gender literacy equtis } \\
\text { Tehsil fixed effects } \\
\text { Intercept }\end{array}$ & $\begin{array}{l}0.712^{* * *} \\
(0.0694)\end{array}$ & $\begin{array}{c}0.0328 * * * \\
(0.00296)\end{array}$ & $\begin{array}{c}-0.0169 * * * * \\
(0.00196)\end{array}$ & $\begin{array}{c}-0.0183^{* * * *} \\
(0.00164)\end{array}$ & $\begin{array}{c} \\
-4.488^{* * * *} \\
(0.119) \\
\end{array}$ & $\begin{array}{c}0.271 * * * \\
(0.0961) \\
-0.0120^{*} \\
(0.00697) \\
-0.00330 \\
(0.00243) \\
0.00155 \\
(0.00286) \\
0.0360^{* * * *} \\
(0.00593) \\
\\
-4.281^{* * * *} \\
(0.385) \\
\end{array}$ & YES \\
\hline $\begin{array}{l}\text { Pseudo R-squared } \\
\text { AIC } \\
\text { BIC } \\
\text { VIF MAX } \\
\text { AVERAGE VIF }\end{array}$ & & $\begin{array}{c}7146 \\
397 \\
0.15 \\
3569.0 \\
3782.1 \\
7.35 \\
1.94\end{array}$ & $\begin{array}{c}6570 \\
365 \\
0.16 \\
3371.1 \\
3581.6 \\
7.09 \\
2\end{array}$ & $\begin{array}{c}6570 \\
365 \\
0.15 \\
3407.5 \\
3618.0 \\
6.64 \\
1.97\end{array}$ & $\begin{array}{c}6570 \\
365 \\
0.16 \\
3388.2 \\
3598.7 \\
6.73 \\
1.98\end{array}$ & $\begin{array}{c}6570 \\
365 \\
0.17 \\
3321.8 \\
3532.3 \\
7.14 \\
2\end{array}$ & $\begin{array}{c}6570 \\
365 \\
0.18 \\
3318.9 \\
3556.6 \\
20.14 \\
3.48\end{array}$ & $\begin{array}{c}3834 \\
213 \\
\\
2429.8 \\
2598.6 \\
6.55 \\
1.92 \\
\end{array}$ \\
\hline
\end{tabular}


